\title{
Reviews of
}

\section{"Seroprevalence of SARS- COV-2 Antibodies in Scottish Healthcare Workers"}

\author{
Tim Bruckner ${ }^{1}$, Tatjana Vilibić-Čavlek ${ }^{2}$, Vladimir Savic ${ }^{3}$, \\ Petros Galanis ${ }^{4}$, Ian Cockburn ${ }^{5}$, Thomas Roederer ${ }^{6}$ \\ ${ }^{1}$ University of California Irvine, Public Health, \\ ${ }^{2}$ Croatian Institute of Public Health: Hrvatski zavod za javno zdravstvo, Department of Virology, \\ Croatia, \\ ${ }^{3}$ Croatian Veterinary Institute: Hrvatski veterinarski institut, \\ ${ }^{4}$ National and Kapodistrian University of Athens: Ethniko kai Kapodistriako Panepistemio \\ Athenon, Faculty of Nursing, Athens, Greece, \\ ${ }^{5}$ Australian National University, John Curtin School of Medical Research, Australia, \\ ${ }^{6}$ Statistician/Epidemiologist, Epicentre, Research, France
}

Published on: Dec 17, 2020

DOI: $10.1162 / 2 \mathrm{e} 3983 f 5 . f 852 \mathrm{e} 5 \mathrm{ed}$

License: Creative Commons Attribution 4.0 International License(CC-BY 4.0) 
To read the original manuscript, click the link above.

Summary of Reviews: This study reports a greater seroprevalence for antibodies among healthcare workers compared to the general population. Reviewers mentioned concerns over selection of the general population, response bias, and adjusting for potential cross-reactivity with other coronaviruses.

Reviewer 1 (Tim Bruckner) | ०००

Reviewer 2 (Tatjana Vilibić-Čavlek, Vladimir Savic) | प्रा०

Reviewer 3 (Petros Galanis) |

Reviewer 4 (Ian Cockburn) | प्म००

Reviewer 5 (Thomas Roederer) | पढ口 $\square$

\author{
RR:C19 Strength of Evidence Scale Key. \\ प

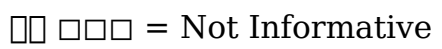 \\ प्र० $\square \square=$ Potentially Informative \\ प्राप्र = Reliable \\ प्राप्र = Strong
}

To read the reviews, click the links below. 